\title{
Penerapan alat pengering hybrid dalam meningkatkan produktivitas dan higienitas ikan sepat kering
}

\author{
Dessy Maulidya Maharani ${ }^{1}$, Agung Nugroho ${ }^{2}$, Agung Cahyo Legowo ${ }^{3}$ \\ ${ }^{1,2,3}$ Fakultas Pertanian, Universitas Lambung Mangkurat
}

\begin{abstract}
The increasing price of Sepat salty fish during rain season is one problem of food producers in Martapura city. Higher price mostly caused of decreasing ability to dry out the fish. In addition, The product of salty fish is not hygienic because of unprotected process from dust and insect. The solving of this problem is modification of dried fish process using Hybrid drying machine (solar-stove combination). The aim of this programme are improving community knowledge about the fish nutrition value, educating community on hygienic drying methods, increasing of dry fish productivity and improving community knowledge on diversification product of salt fish. The target community for this programme is in the Tambak Baru ulu village of Martapura district of Banjar regency. The Methods of this programme are courses, discussions and training. The results of this community services activities showed that the community get knowledge about the nutritional value of Sepat Fish, skills to dry fish using a Hybrid dryer, increases dry fish productivity during rain season and ability to diversify of dry fish products.
\end{abstract}

Keywords: sepat fish, drying, solar stove, Martapura

\section{PENDAHULUAN}

Ikan memiliki banyak manfaat bagi manusia. Manfaat ikan bagi manusia bisa dilihat dari aspek nilai gizi dan aspek ekonomi. Oleh karena itu ikan adalah bahan makanan yang sangat menarik untuk dijadikan komoditi penunjang kesejahteraan Masyarakat.

Bahan makanan yang mengandung asam amino essensial sangat diperlukan oleh tubuh. Bahan tersebut banyak terdapat di dalam ikan. Selain asam amino ikan sangat mudah dicerna oleh tubuh karena memiliki jaringan pengikat yang sedikit (Naiu, 2011).

Dari segi Ekonomi ikan juga termasuk komoditi yang penting. Ikan adalah sumber daya yang dapat diperbaharui. Pengolahan ikan berkelanjutan dapat meningkatkan kesejahteraan Masyarakat terutama didaerah pedesaan. Ikan akan bertambah nilainya jika diolah menjadi komoditi yang memiliki umur simpan lebih panjang. Untuk memperpanjang umur simpan ikan dapat dilakukan pengeringan ataupun melakukan modifikasi kemasan (Warsiki et al., 2013)

Desa Tambak Baru Ulu adalah desa yang berada tepat di bantaran Sungai Martapura. Wilayah ini masuk dalam Kecamatan Martapura.
Seperti banyak desa lainnya dibantaran sungai martapura sebagian besar mata pencarian masyarakatnya di bidang pertanian. Selain bertani mereka juga melakukan kegiatan pengolahan ikan kering khususnya Ikan Sepat. Karena itu desa ini dikenal dengan penghasil Ikan sepat kering asin di daerah Martapura. Kegiatan pengolahan ikan ini banyak dilakukan setiap hari atau diwaktu senggang untuk menambah penghasilan jika tidak sedang bertani. Pemasaran olahan ini dilakukan sendiri oleh mereka maupun dijual ke pengepul ikan kering. Peminat sepat olahan ini sangat banyak, terbukti dengan luasnya daerah pemasaran baik Kalimantan Selatan maupun keluar kota seperti Kalimantan Tengah dan Kalimantan Timur. Ikan sepat yang mereka olah hanya ikan sepat asin kering.

Pada musim penghujan harga ikan sepat kering sangat mahal bisa mencapai Rp $60.000 / \mathrm{Kg}$ padahal jika produk sedang melimpah harganya bisa sepertiganya saja. Hal ini tentu sangat berimbas bagi pelaku usaha yang menggunakan ikan sepat kering sebgai bahan baku. Oleh sebab itu perlu upaya modifikasi proses pengeringan dengan menggunakan menggunakan alat pengering kombinasi tungku surya. 


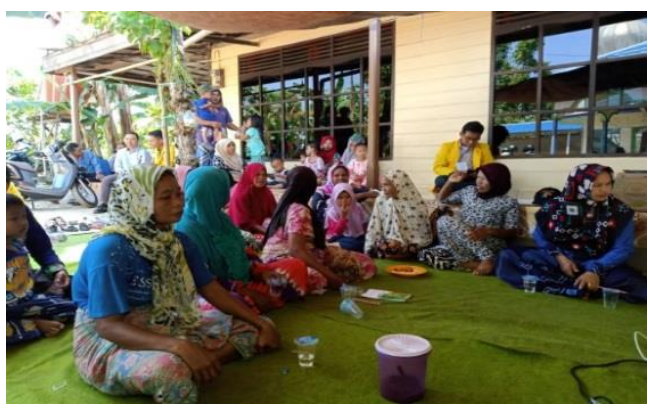

Gambar 1. UKM Mitra PKM yang didominasi ibu rumah tangga

Program ini dilakukan dengan melibatkan Kelompok Mitra Barakat Mulia dan Barakat Manuntung. Kedua kolompok mayarakat ini bermukim di Desa Yambak Baru Ulu, Kecamatan Martapura Kabupaten Banjar, Kalimantan Selatan. Analisis situasi Mitra:

1. Pada musim hujan bahan baku ikan sepat melimpah.

2. Pada saan musim hujan Mitra tidak bisa menjemur ikan sepat.

3. Penjemuran ikan sepat masih mengandalkan sinar matahari.

4. Penjemuran ikan sepat hanya menggunakan alas Daun Rumbia dan diletakkan di area terbuka bahkan dipinggir jalan.

5. Ikan Sepat kering yang dihasilkan memiliki kadar air yang tinggi sehingga mudah rusak.

6. Mitra menggunakan konsentrasi garam yang tinggi untuk memperpanjang umur simpan produk sepat kering.

7. Ikan Sepat kering yang dijual tidak dikemas dengan menarik.

8. Mitra setempat memiliki minat yang rendah terhadap Ikan Sepat bila belum diolah

9. Belum ada diversifikasi produk Ikan Sepat kering oleh mitra.

Tujuan Program ini adalah:

1. Mengedukasi mitra mengenai nilai gizi Ikan Sepat.

2. Mengedukasi mitra mengenai alat dan metode penjemuran yang Higienis.

3. Meningkatkan produktivitas Mitra dalam menghasilkan Ikan Sepat kering.

4. Mengedukasi mitra mengenai diversifikasi produk olahan Ikan Sepat.

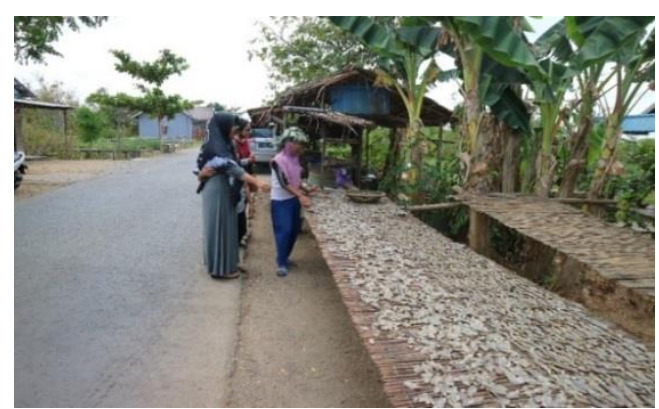

(a)

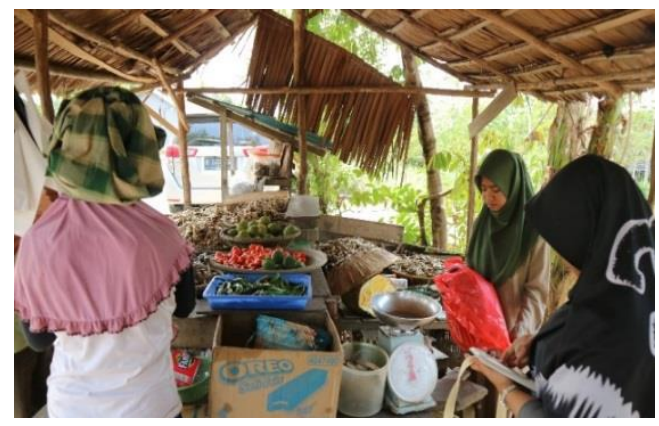

(b)

Gambar 2. (a) UKM Mitra menjemur ikan di pinggir jalan (b) UKM Mitra menjual ikan di samping penjemuran ikan

\section{METODE PELAKSANAAN}

\section{A. Waktu dan Tempat Kegiatan}

Kegiatan dilaksanakan selama tiga Bulan yaitu dari bulan Juli 2019 sampai bulan September 2019. Kegiatan dilaksanakan di Fakultas Pertanian ULM Banjarbaru dan di Desa Tambak Baru Ulu, Kecamatan Martapura, Kabupaten Banjar.

\section{B. Tahapan Pelaksanaan}

Tahapan Pelaksanaan kegiatan ini adalah sebagai berikut:

\section{Persiapan}

Pada tahap ini ditentukan audiens atau sasaran yang ingin diberikan peyuluhan dan pelatihan. Sasaran yang dipilih adalah Mitra usia produktif berprofesi sebagai petani, iburumah tangga maupun pembuat ikan asin sepat berada di wilayah sentra ikan sepat.

Persiapan dilakukan bersama-sama oleh dosen dan mahasiswa sebagai satu tim. Beberapa mahasiwa dan dosen mengurus perizinan baik dari pihak kampus maupun pihak desa. Hal tersebut dilakukan dalam usaha konsolidasi dan sinkronisasi penyelenggaraan kegiatan. Selain per- 
izinan dipersipakan juga materi penyuluhan, bahan pelatihan dan bahan diskusi.

2. Pelaksanaan

Pada tahapan pelaksanan metode yang digunakan dalam kegiatan ini berupa ceramah, Diskusi, Pelatihan dan Demonstrasi. Adapun Kegiatan yang disampaikan adalah:

a. Memperkenalkan kelebihan ikan sepat.

b. Perancangan dan pembuatan alat pengering.

c. Uji coba pengeringan.

d. Pengenalan alat pengering kepada Mitra.

e. Melatih dan mendampingi mitra melakukan pengeringan.

f. Melatih dan mendampingi mitra melakukan diversifikasi produk.

C. Metode yang Digunakan

Metode yang digunakan dalam kegiatan ini adalah sebagai berikut:

1. Ceramah dilakukan pada kegiatan perkenalan kelebihan ikan sepat, perkenalan alat pengering dan pendampingan diversifikasi produk diskusi, dan tanya jawab.

2. Diskusi dan Tanya Tanya Jawab Ceramah dilakukan pada kegiatan perkenalan kelebihan ikan sepat, perkenalan alat pengering dan pendampingan diversifikasi produk.

3. Diskusi Internal dilakukan pada kegiatan perancangan dan pembuatan alat penegringan serta uji coba pengeringan.

4. Pelatihan dan Demonstrasi dilakukan pada kegiatan pendampingan pengeringan dan diversifikasi produk.

\section{HASIL DAN PEMBAHASAN}

\section{A. Memperkenalkan Kelebihan Ikan Sepat}

Kegiatan ini dilakukan untuk meningkatkan pengetahuna Mitra mengenai kelebihan ikan sepat baik dari Nilai Gizi dan Nilai ekonomisnya. Pada kegiatan ini dipaparkan mengenai Nilai gizi ikan sepat, cara penyajian serta nilai tambah yang akan didapatkan dari pengolahan ikan tersebut.

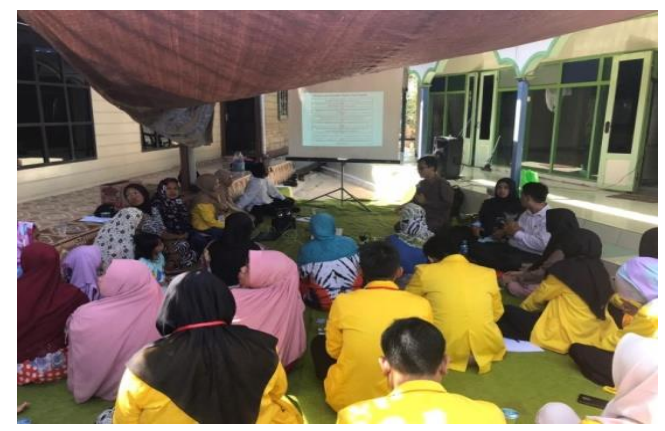

(a)

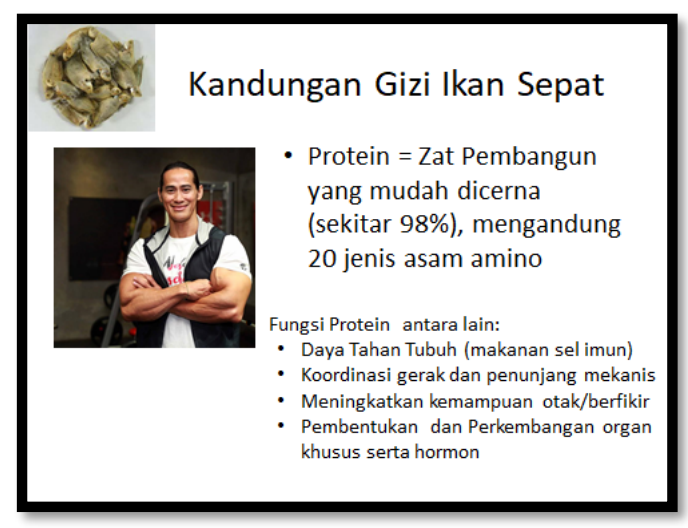

(b)

Gambar 3. (a) Kegiatan pengenalan nilai gizi ikan sepat kepada masayarakat, (b) Contoh slide presentasi

\section{B. Perancangan dan Pembuatan Alat Pengering}

Kapasitas alat pengering yang dirancang disesuaikan dengan kebutuhan dilapangan untuk satu hari penjemuran. Alat tersebut berkapasitas 10 Kg dalam satu hari penjemuran setara dengan Rak sepanjang 5x1 meter yang digunakan oleh Mitra. Rangka tebuat dari steinless stell dengan dinding kaca. Alat ini terdiri dari empat rak. Tiap rak mampu menampung 2,5 kg ikan sepat segar.

Prinsip pengeringan alat ini menggunakan dua sumber panas yaitu tenaga surya dan tungku gas LPG. Adanya dua sumber panas tersebut membuat alat ini bisa difungsikan dalam berbagai cuaca. Untuk controller, alat ini menggunakan tenaga listrik. Suhu maksimum alat ini dengan batuan sinar matahari adalah $60^{\circ} \mathrm{C}$ sedangkan dengan gas bisa mencapai $>90^{\circ} \mathrm{C}$. 


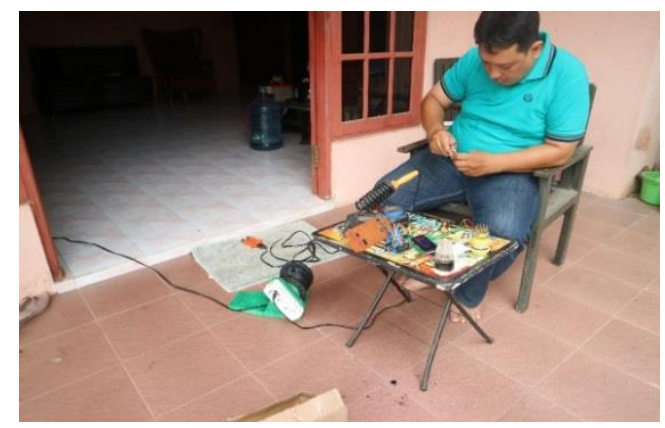

(a)

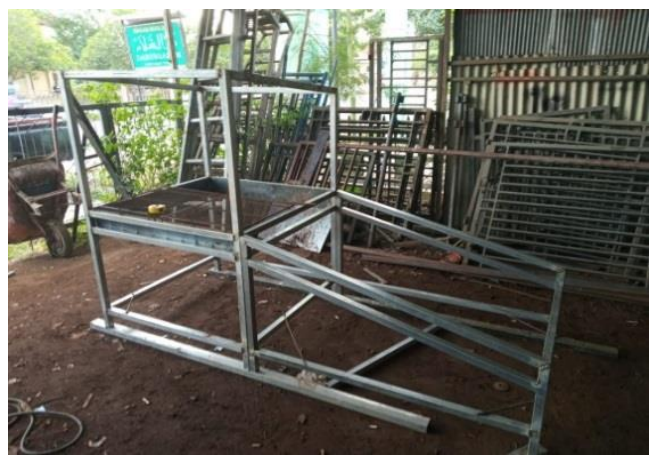

(b)

Gambar 4. (a) Pembuatan kontroler, (b) Pembuatan rangka

\section{Melakukan Uji Coba Pengeringan}

Uji coba pengeringan dilakukan untuk mendapatkan lama penegringan dan juga konsentrasi garam yang sesuai denggan keinginan pasar dan SNI. Dalam dua hari pengeringan mengguna-kan panas matahari kadar air ikan berkurang dari sekitar $73 \%$ menjadi rata-rata $12 \%$.

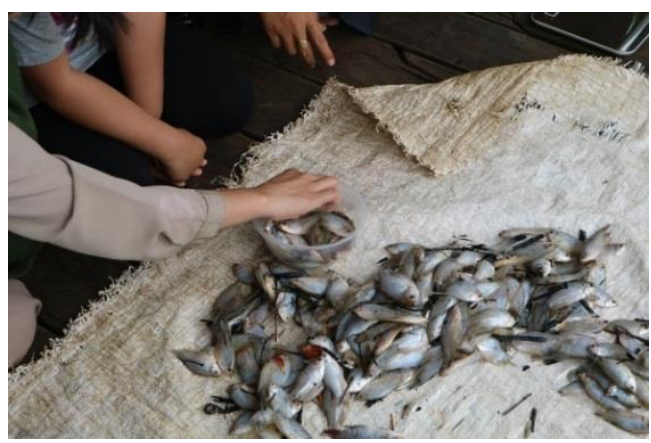

(a)

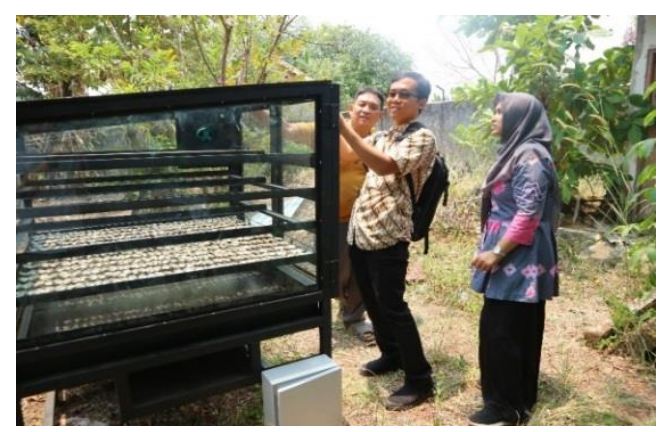

(b)

Gambar 5. (a) Pembersiham dan penimbangan ikan, (b) Pengukuran suhu

\section{Memperkenalkan Alat Pengering ke Mitra}

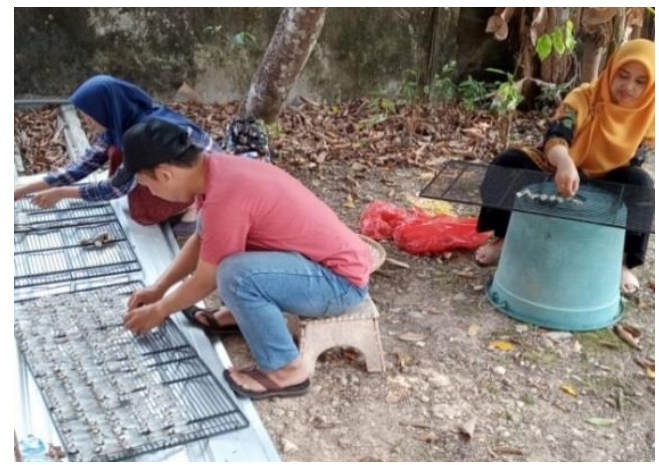

Gambar 6. Alat pengering

Pada tahapan ini Mitra mendapatkan ceramah dan melakukan demonstrasi pengeringan ikan sepat menggunakan alat pengering mode hibri. Pada tahap ini kembali didapat feedback dari Mitra untuk penyempurnaan alat pengering yang telah dibuat.

\section{E. Melatih dan Mendampingi Mitra melakukan Pengeringan}

Pada tahap alat penegring yang telah sesuai dengan kebutuhan Mitra disistribusikan ke Mitra. Proses pemanfaatan alat dan pembuatan produk tetap didampingi. Proses pendampingan dilakukan selama 2 minggu. Selelah 4 minggu Mitra secara mandiri dapat mengoperasikan alat pengering Hybrid dan membuat produk sesuai keinginan pasar. 


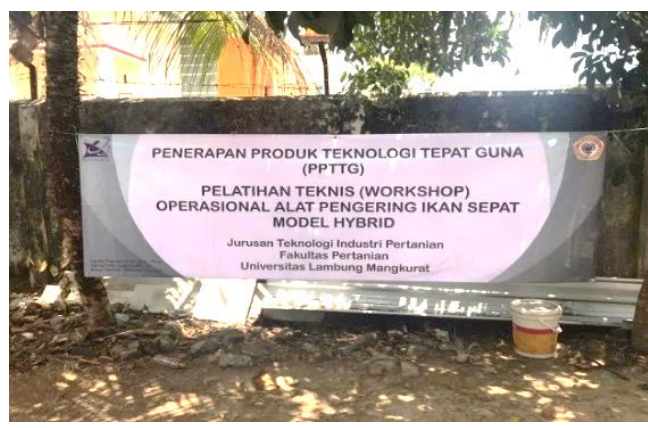

Gambar 7. Pelatihan teknis operasional alat pengering

F. Melatih dan Mendampingi Mitra melakukan Diversifikasi Produk

Pelatihan kepada mitra dilakukan dengan metode demonstrasi di tempat mitra. Produk yang di buat adalah Abon Ikan Sepat, Tepung Ikan Sepat dan Balado Ikan Sepat. Pada tahap ini masyarakat sangat antusias dan sangat menyukai produk yang dibuat. Bahkan setelah pendampingan masyarakat langsung mencoba membuat produk secara mandiri dan berhasil.

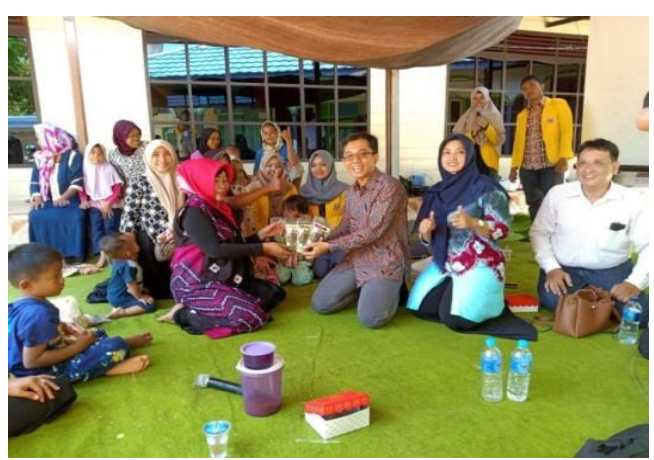

(a)

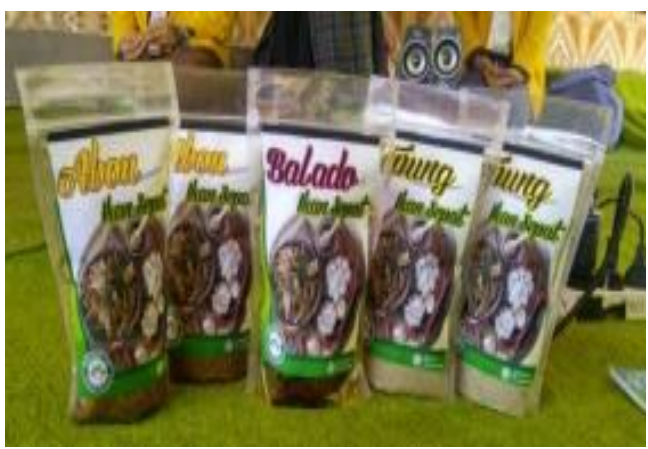

(b)

Gambar 8. (a) Pelatihan diversifikasi, (b) Produk akhir abon, tepung dan balodo ikan sepat

\section{KESIMPULAN}

Kesimpulan yang didapat dari pelaksanaan program ini adalah:

1. Mitra Program mendapatkan pengetahuan mengenai nilai gizi Ikan Sepat.

2. Mitra memiliki keterampilan mengeringkan ikan menggunakan alat pengering Hybrid.

3. Alat Pengering Hybrid dapat difungsikan pada saat musim hujan sehingga produktivitas mitra meningkat.

4. Mitra memiliki kemampuan untuk mendiversifikasi produk Ikan Sepat kering.

\section{UCAPAN TERIMA KASIH}

Ucapan terima kasih disampaikan kepada Direktorat Jendral Penguatan Riset dan Pengembanagn Kementrian Riset, Teknologi dan Pendidikan Tinggi yang telah mempercayai program ini untuk dibiayai. Rektor Universitas Lambung Mangkurat Dalam Hal Ini Lembaga Penelitian dan Pengabdian Masyarakat atas arahan, kerjasama dan pembinaanya selama proses kegiatan ini. Terimakasih tekaterhingga juga diucapkan kepada para Mitra, Perangkat Desa dan seluruh pihak yang sudah berkontribusi dalam mendukung dan menyukseskan terlaksananya rangkaian program ini.

\section{DAFTAR PUSTAKA}

Naiu, A S. (2011). Perkembangan Terkini Perubahan Selama Penurunan Mutu Ikan Basah. Jurnal Saintek Vol 6:2.

Endang Warsiki, Titi Candra Sunarti, Lala Nurmala, 2013. Kemasan Antimikrob untuk Memperpanjang Umur Simpan Bakso Ikan. Jurnal Ilmu Pertanian Indonesia. Vol. 18 (2): 125-131. 